\title{
Polish Regional State Television - On the Border Between Regional and National Television. The Evolution of the Profile of Regional Television Stations
}

\begin{abstract}
Since the collapse of the monopoly of Telewizja Polska (TVP - National Polish Television), the issue of field branches of TVP remains unresolved actually to this day. Numerous attempts have been made throughout the years to establish the status and functioning rules of the branches within the structure of TVP. Also, the concept has been sought to determine their position and role on the TV market. The years of attempts to restructure regions have brought no expected outcome. The proposed solutions ranged from the concept of a "network" during the 1990s, through attempts at programme and managerial integration in the late $20^{\text {th }}$ century, to the endeavours to profile channels. Instead of improving the situation, they caused even greater chaos to the branches and further deteriorated their already difficult financial situation. Changes were to be brought by a new concept of the functioning of field branches of TVP S.A., proposed towards the end of 2015. It assumed the reorientation of the philosophy of the regions and abandonment of "regional television" in favour of "the television of the regions." But personal changes to the Management Board of TVP stopped the planned reform. This article presents the chronology of the planned and implemented reforms, from 1990 to 2015, in the scope of channel profile and the programme platform of field branches of TVP S.A.
\end{abstract}

Key words: Polish Regional State Television, program strategy, reform, TVP S.A., program format.

\footnotetext{
A $\mathrm{s}$ a direct result of the loss of its monopoly, Polish State Television was obliged to establish the guidelines which would enable regional television stations to find their niche in the free market reality of the media. The concept of this functioning as well as the place of regional television stations in the structure of TVP was therefore the object of consideration of those who were charged with formulating the shape of the media system in Poland after the fall of Communism in 1989. The first attempt
} 
to delineate the status as well as the ground rules for regional television stations were worked out by the Commission for the Reform of Radio and Television in 1990 (Gtówne, 1990, s. 29). It was proposed at that time, that until the individual local television stations would be able to obtain the necessary financial and technological wherewithal to become independent, they would be allowed to transmit their own programs on Saturdays for 2-3 hours, instead of showing what TVP 1 was broadcasting in this time slot. Irrespective of this initiative, if was suggested that these stations extend their daily programming by 1-2 hours, and eventually transferring them to TVP 1 for one hour (Gtówne, 1990, s. 29). This proposed solution, despite its never being introduced, was the basis for a solution which was implemented in later years - of a mass-produced program structure, with national and regional time slots.

In addition to these propositions aimed at making local programs independent, well as a decentralization of the programs of TVP in general, a solution was also put forth regarding the functioning of the local television stations. Some were of the opinion, that the local TVP television stations should be transformed into a network of regional TVP television stations, which would cover the whole country. In addition, it was thought that the structure of the television would come down to the local level, through the creation of local television studios (Główne, 1990, s. 29). It would seem therefore, that the commission attempted to lay a foundation for the television market, similar to the structure of the print media market, taking into consideration the national, regional, and local markets. This goal was never attained, however. As successive years have demonstrated, the TVP has yet to find an idea for its local affiliates, in its structure as well as on the television market, nor has it elaborated a long-term strategy for the development of its regional subsidiaries.

At the same time, a discussion on the new shape of Polish television has been held outside of the structure of the Radio and Television Commission. The result was the proposition for a new bill, drawn up by a group of directors of local television stations. According to this bill, theses televisions were to be independent entities (initially foundations, and later public corporations), transmitting regional programs, as well as other programs together with the directors of TVP 2. On the other hand however, TVP 1 was to be an organization which operated independently. The fight against breaking up Polish state-run television in this manner, lasted three years. The result was a solution which was written into the Radio and Television Bill, which determining that TVP was one company with 
affiliates throughout the country. As Karol Jakubowicz, who was working on redesigning Polish television, points out, it was finally decided to not have all the local affiliates become independent, but rather to make of them subsidiaries of a national company (Jakubowicz, 1996, s. 65). The model accepted was based on the supposition that local affiliates should become independent regional television stations, each of which would possess its own frequencies, and transmitters, and would broadcast its own programs throughout the day. Such an interpretation of the tasks of regional television inherently contains the broad implications. On the one hand this has led to the assuring that these stations would transit some fifteen hours a day of regional programming, and on the other hand its is linked with necessity of assuring the necessary technical, organizational, and financial conditions,. The regional affiliates were obliged therefore to transmit on the appropriate frequencies, as well as guarantee that their transmitters were sufficiently powerful. In the affiliates themselves, numerous and capital-intensive investments were required, for equipment, and the production-transmitting infrastructure. In addition, it also turned out necessary to introduce soft budget limitations to dependent upon tolerating the ever-increasing financial losses of these affiliates (Reforma, 1999, s. 116). Moreover, due to the inclusion of the local affiliates into the structure of TVP S.A. (Polish Television Incorporated), significantly complicated the internal organization of TVP, as well as creating problems for its management. It is also noteworthy, that the increasing interest in regional television by political organizations and other special interest groups, intensified other types of pressure exerted on these regional stations (Jakubowicz, 1999, s. 184). It was exactly in such formal-legal conditions, that since 1992, the process of the launching of regional programming by the local affiliates of TVP was initiated. All of thee factors resulted in regional television being, from its very inception, burdened with multi-level risks. Also worthy of attention is the fact that over the years, in spite of a tight budget, new regional television stations were created. Article 64 of the Radio and Television Bill of 1992, enumerates 11 regional affiliates, which the Minister of Finance was to have established. These stations were in Bydgoszcz, Gdańsk, Katowice, Kraków, Lublin, Łódź, Poznań, Rzeszów, Szczecin, Warsaw and Wrocław. Later - in 1996 - a station was opened in Białystok (Grzybczak, 2002, s. 19). As Bogusław Nierenberg has pointed out, the creation of TVP affiliates in only 12 cities, has aroused frustration in other towns, which after administrative reforms carried out in Poland, had become provincial capi- 
tals, and still didn't possess their own regional television stations. Kielce, Olsztyn, Opole, and Zielona Góra were amongst these cities. The establishment of regional branches of TVP only 12 cities, aroused frustration in other centers, especially those four, that after the administrative reform of the country were the capitals of provinces, and not have their own regional TV. This was Kielce, Olsztyn, Opole and Zielona Góra (Nierenberg, 2007, s. 50). In the end however, the board of directors of TVP awarded the status of regional television center, to its affiliates in Gorzów Wielkopolski, Opole, Kielce, and Olsztyn. There are therefore, currently, in the structure of Polish state-run television, 12 local 12 local affiliates and 4 regional centers. So finally, in early 2001 the board of TVP gave the status of centers of television editors in Gorzow Wielkopolski, Opole, Kielce and Olsztyn in the structure of public television so now operates 12 regional branches and 4 the regional centers (Grzybczak, 2002, s. 19).

The next element, which to a certain extent, somewhat complictes the situation of the regional centers, were the amendments to the Radio and Television Bill (Ustawa, 1992) of 1992, which gave them a completely different status than previously. First of all, the bill obliged public television to transmit regional programs (which Telewizja Polska had not done previously) and also required the minister of communication as well as the KRRiT (the National Council of Radio and Television) with this goal in mind, to furnish these stations with their own broadcast frequencies. Second the right to undertake key decisions in matters concerning the fate of these stations, including questions regarding the sharing of national television subscriptions between headquarters and the affiliates, and the share of program production of the affiliates of the national air time of TVP 1 and TVP 2, was given by the bill to the KRRiT. This was done in such a manner, as to render it impossible for the headquarters of TVP in Warsaw to discriminate against local affiliates. TVP thereby having at its disposal, its headquarters in Warsaw as well as 11 local stations, broadcast: two national channels, one satellite channels, a channel transmitted in a separate network of TVP 2 (a channel with 11 affiliates, broadcast on TVP 2's frequency, but cut off, at certain times of the day, from its national channel) as well as 11 regional channels (which are local stations transmitting on their own frequencies (Jakubowicz, 1996, s. 65).

It soon became apparent however, that dreams of a network of local television stations which could produce regional programs from start to 
finish, was impossible. These local affiliates could produce on their own programs, which occupied only $30 \%$ of air time, and at least of programs would be imported. Their programs would be supplemented by the retransmission of programs from TV Polonia, and other sources, and would have nothing about life in their respective regions. This state of affairs resulted mainly from the fact that TVP S.A. didn't possess the necessary funds to finance 15 independent channels (2 national channels, one satellite channel, and 12 regional channels). One of the manners to solve this situation was to create cooperation amongst the various affiliates (Jakubowicz, 1999, s. 184). The awareness of the fact that TVP S.A. was incapable of maintaining such a costly operating model of its local affiliates for any length of time, already led the board of directors of the company, in September 1994, to initiate a "common program and acquisition policy" (Reforma, 1999, s. 117). This cooperation was defined as being "Formula 12 " of "the network". Its idea was based on the concept that Regional Television its own programming, lasting for several hours, dedicated to local subjects, and that the rest of the airtime should be a common program. The programming of these local station should therefore consist of three parts: The first of these should consist of broadcast from a given city, emitted on separate frequencies, and designed for the inhabitants this city and the surrounding region. This task would be accomplished, based on the local station's financial and personnel resources (Mielczarek, 1996, s. 67).

The second type of program, would consist of those broadcasts emitted in the co-called "network", which commenced operations on September 4, 1994. The "Bureau of Local Affiliates" was created on April1, 1994, with this goal in mind (Grzybczak, 2002, s. 23).

The channels in their respective cities would transit the same program, for four hours, on a daily basis. The concept is that thereby, costs would be lowered and revenue from advertising would be increased (Jakubowicz, 1996, s. 66). These programs would be created thanks to the cooperation of several regional stations, or programs broadcast, which were purchased by these stations in common. During the day, the word "network" would appear on the screen three times when these stations shared airtime. The first time slot - for children and young adults, would be broadcast from 15:10 to $16: 30$ The second time slot would be from 17:35-18:00 and would be for soap operas. The third time slot, which would offer feature and documentary films, would be broadcast from 19:15 to 21: 15 . These regional programs would be broadcast over an are of approximately $1 / 4$ of 
Poland's area and could be viewed by some $28 \%$ of its population (Mielczarek, 1996, s. 67). A portion of the airtime on local television would be occupied by a retransmission of programs from the „TV Polonia” satellite channel (Jakubowicz, 1996, s. 66).

The third element however was the transmission of the "Combined Channel Two Network", that is broadcasting a regional program on the time slot of TVP 2. This program could potentially have 17.5 million viewers. In total, Polish national television broadcast only 1,200 hours of programs which made outside of Warsaw, which composed $8 \%$ of total programs broadcast. At the end of the 1980s, programs from outside of Warsaw were almost $20 \%$ of those broadcast. As Tomasz Mielczarek points out, its very beginning TVP there was never a precise vision as to the fate of regional television. At the end of 1995, the dominant view was that the Western European model, where the number of local television stations and the financial means designated for their activity should be limited, prevailed (Mielczarek, 1996, s. 67).

The place for regional television in the structure of TVP, also became a subject of consideration for the National Radio and Television Council (KRRiT). In a document accepted in 1995 (Przyszłość, 1995, s. 26) it was stressed that in as much as the bill radio and television imposed upon public television the obligation of creating and distributing regional programs, it didn't provide a very precise concept of how these programs should look. First of all, the concept of "region" was not defined. Which would have undoubtedly assisted in establishing the proper territorial range of such a program. Second, the concept of "regional program" was not specified, which is especially significant, on the one hand in defining the character or value of such a program, and the other, by establishing the proportion between programs made by a specific affiliate station, and those from outside of the region. In addition, as the regulator pointed out, the bill indicates two directions of decentralization of TVP S.A. On the one hand it's a program decentralization, dependent upon the formation of regional programs, and on the other however, it's a production decentralization, requiring the production of a part of the national programs by various affiliate stations, with the aim of taking advantage of the intellectual potential of the whole country, and reflecting in these programs all of the regions. The regional stations, in their long-term program developments, were to, as may be seen in the document, determine which model of decentralization, or what combination of various types of decentralization, would be the most suitable in Polish conditions from the viewpoint 
of the viewers, the program goals, as well as the means which TVP S.A. will dispose of (Przyszłość, 1995, s. 26). The situation in the TVP S.A. itself however, was not quite so obvious. As Jarosław Grzybczak admits, successive boards of directors of TVP didn't find a manner to justify the functioning of the regions and formulated a series of objections against regional programs. These objections principally focused on such problems as:

- de-concentration of means for the production of a program, that is copying a program for several or more affiliate stations;

- incomplete and ineffective use of the technological-production possibilities - an excess of employees and therefore high labor costs;

- a fall in the proportion of regional television on the television market as a whole (Grzybczak, 2002, s. 25).

In addition, another weakness of the local stations was the lack of a well-defined mission, resulting from an undefined station format as well as the lack of advertising offers (Reforma, 1999, s. 117).

In essence, the regional television system was perceived to be excessively costly and rendered an effective taking advantage of the possibilities which TVP offered. The result of this state of affairs were activities which were to ameliorate the work of the regional stations and improve the economic situation of public television. Over the course of successive years, attempts were undertaken to improve the situation of regional affiliates. The supposition - accepted in March 1998 - of the "Strategy of Partnership in Regional Television" was accepted. In practice this led to a further broadening of common time slots (extended in total to more than 10 hours a day) as well as the synchronization of the program format of the local stations (Grzybczak, 2002, s. 25). Yet another attempt to modify the regional television stations was linked with changes introduced by the "General Schedule for the Implementation of Reforms in TVP S.A." There was also a planned streamlining of the financial system of the regional stations of TVP. These changes were therefore planned to improve the system of broadcasting and obtaining advertising on regional television. This was due to the fact that there were plans to introduce a universal advertising rate for all stations as well as their being able to transmit specific commercials only in selected stations. In April 1998, a reorganization of the "Bureau of Local TVP S.A. Stations" was initiated, to coordinate the programs and advertising of the Network. The activities undertaken, however, did not produce the expected results. The joint time slots for regional television - "Formula 12" - which was launched with 
great fanfare in September 1998, did not provide public television with the expected successes. In the Autumn of 1998, the viewership of public regional television not only didn't increase, it even slightly decreased (it fell below $6 \%$ of market share). The interest of potential advertisers was not aroused by the programs of regional television, and TVP was not able to create an effective system for the acquisition of advertising. The formation of a separate advertising agency for all the regional stations was postponed until a later date (Grzybczak, 2002, s. 25).

The remaining indicators fell at the same time with the worsening financial situation. Even though airtime for regional programs was being reduced, there was not a parallel and proportional reduction in the cost of the activities of local stations. Additionally, the effectiveness of these local stations, understood as the source generating viewers, as well as advertising revenue, was disproportionate to the input. Meanwhile, regional stations were, in 1998 and the first quarter of 1999, were loosing the majority of their viewers to commercial television stations. The regional stations were being marginalized, in effect to the status of niche television stations (Reforma, 1999, s. 118).

The next opportunity for resolving the problems of the regional affiliates, appeared in 1999 together with a document accepted by the board of directors of TVP dealing with reforms in Telewizja Polska (Reforma, 1999, s. 118). These reforms were to include the regional affiliates on two basic levels: management and programming. As far as changes in management went, it was planned to conduct the process of integrating the local affiliates with the Rest of the company, and include them in the same management scheme, as the other organizational entities. Local stations were to become self-financing entities, and their running costs were to be covered by subscriptions as well as revenue generated by these stations on their own. In addition, an employment restructuring was to be conducted, where it was assumed that the workforce should be reduced by $25 \%$. It should be emphasized moreover, that outsourcing was considered - that is the spinning off of some functions which heretofore were performed by full-time employees of these television stations, to other companies. The need to cut costs was supposedly behind these measures. In the sphere of programming, this reform consisted of dividing the broadcasting and producing functions of these stations, as well as undertaking an attempt to define the tasks, which the regional stations were to carry out. Therefore in their own time slots, as well as in those of TVP 2, they were to concentrate on, amongst others, regional news, and reflect 
the life of the local community, as well as complete the task of civic education. In the common time slots, they were to, as far as subject master goes, present programs presenting the various regions of Poland - their diversity, institutions, uniqueness, and problems. The program choice was also supposed to include shows for specific target groups, self-help programs, and those broadcasts which had to do with cooking and entertainment, films and documentary and educational series, and also licensed programs. In addition, viewers were supposed to be able to see transmissions and retransmissions of Polish and foreign sports events. Theses stations were also to broadcast game shows, and shows which had audience participation. It was also assumed that they would show selected feature films, which had their television premiers on TVP 1 and 2, and also reruns of the most interesting programs broadcasted in other TVP programs.

Moreover, a delineation of the time slots was attempted. Their own time slots were to be dedicated to what was produced in their own stations, and the total time of these programs was to be 240 minutes a day, and divided into 4-6 blocks. Such a solutions was to enable the local stations to quickly react to important events in the region, by transmitting the news several times a day. Moreover, these stations had the possibility to, in specific situations, to cut into a common regional-national program with their own material. The programs of the joint time slots was in turn to have been determined by the Regional Programming Bureau, in accordance with the directors of the local stations. A certain novelty appeared with the introduction of semi-disconnected time slots, which were to allow some stations, disposing of the necessary financial and organizational possibilities, to broadcast their own additional programs (Reforma, 1999).

What is also noteworthy is the fact that a purely regional character was imposed only in these stations' own time slots. Those time slots held in common, were treated as, on the one hand, one of the rerun channels for the main TVP programs as well as a place for various genres and formats, which were offered by commercial stations. Given the domination in prime-time broadcasting, of the common time slots, such a program policy condemned under-financed regional stations to direct competition with on the one hand, the other TVP channels, and on the other, with commercial television.

In 2000, TVP S.A. reacting to the changes on the electronic media market, worked out a program strategy (Strategia, 2000) which took into 
consideration the opportunities and threats for public television stations resulting from the on-going process of globalization. In this document a characteristic profile of the regional stations as a whole was performer, as well as a vision for the development of the regions until 2003 was presented. With regards to viewers, it was established that in 2000, the audience of regional television were viewers in the 55 and older age group, living in cities of over 100,000 inhabitants, and having a trade-school or secondary education. It was also determined that above all they were people who were not employed, retirees, or housewives. The characteristic program genre was composed of: news, journalistic, documentaries and reporting, educational, sports, as well as programs for children and teenagers. This program range allowed regional television to obtain 3\% of the market share. It was projected that regional television would be able to increase this share to more than $5 \%$ in 2003, as well as to increase viewers in the 16-49 age group, and of children and youths, those viewers who were professionally active, as well as the inhabitants of small cities (Strategia, 2000, s. 22). It's also necessary to stress, that the planned expansion of the regional television target group, was the next step in the confrontation with non-public broadcasters. In addition, it was postulated that the introduction of a program format based on the ever-increasing transmission of local news programs at fixed times, would help viewers navigate through the program choice of Telewizja Regionalna. It was also demanded that the attractiveness of the program be maintained, and that entertainment and commercial content be introduced, which would allow regional television to obtain and maintain a certain level of viewers.

The very shape of the program format from 2000 also deserves some attention.

The programming commenced with a time slot for children, broadcast from 7:00-8:00 in the morning. Next there would be half an hour of the news time slot. From 8:30 to 10:30 there would be soap operas, self-help programs, and infomercials. 10:30 would be the second half-hour news. In order, there would be until 14:00 films, documentaries, entertainment, or self-help programs. 14:00 marked the time for more specialized programming in the regional stations. From 14:00 to 15:00 would be the women's time slot, that is soap operas and documentaries. Starting at 15:00 there was an educational slot for children and young adults, and after that, the next news slot. Following this, there was a family slot, with films and self-help, and at 17:15, there was main, longest news slot commenced, which lasted from 17:15 to 19:00. Further on we have "an offer 
for the public at large" with feature films, reports, and soap operas. From 21:30 to 22:00 we have the fifth news slot and after that, "an offer for the smaller public". Here one could see regional reports, economic self-help, as well as military programs. At 23:00 the days programming ended with final, sixth news broadcast, after which a feature film (Strategia, 2000, s. 23).

The layout of the program format shows that in 2000 the regional stations entered a "fratricidal" competition with both TVP 1 and TVP 2, as well as with commercial stations. Similarily, as the commercial TVN, regional stations had a clear program format, based on slots, from 14:00 with a film-self-help slot, till 18:00 when there was something more directed to a wider public in the so-called prime-time, taking up a rivalry with the main public and commercial stations, as they had the same type of programming, that is, films, soap operas, and reports.

As Edward Miszczak has said, in TVN from morning until 14:00 was the slot for reruns. It was at this time that reports, game shows, docudramas, series, and entertainment programs were shown. This slot ended at 14:00 and at this time TVN started to invest. This was the "middle" slot, when second-rate as well as programs of lesser quality were shown. It was only at 17:00 when there was a larger viewing audience, that TVN would come with programs which were stabilizers for the television viewing public (Świerczyńska-Głownia, 2014, s. 81). There was no competition, as far as the market goes, this was the only slot dedicated to children, which in later years was replaced by a morning slot, which came into direct competition with TVP 1 and TVN.

In May 2001, TVP S.A. worked out its next program strategy till 2004 (Strategia Programowa, 2001). This document was a more precise version of the premises from 2000. Two variants for the development of TVP's local stations were presented here.

The first of them assumed - as in 2000 - that the viewership would expand to include the commercial sector of those in 16-49 age group, as well as people who are professionally active, living in small cities, as well as, what was not supposed earlier, in the countryside. The principles for this program format were to be based on several suppositions.

Above all the program format structure was to be based on permanent, constantly more numerous local news programs. News, broadcast in its own time slots, was to occupy $10.8 \%$ of the program format. It was proposed to increase the number of news broadcasts in the form of short, as well as longer programs, with news from the town and region. News pro- 
grams were to be characterized by a specialization customized according to the time of day of the broadcasts, and the target audience. It was assumed that the news would have a stronger, than heretofore, emphasis on local and community-related problems. It was also stressed that the news should be current, via a rapidity of reacting and a continuation of subjects. There was also to be an interactive cooperation with the institutions of local government, as well as transmissions of important events in the region.

The second pillar of the regional program format was to be the social reporting slot, reporting in general, and documentaries. In this sector, news would be $33.6 \%$ and in the mutual slot, $11.9 \%$. It was assumed that in this are, the programs would feature local values both in Poland and abroad, assist the local society in social adaptation and strengthen the family, and also propagate provincial models, and not elite ones linked with the capital (Warsaw). It was desirable in this area, for the reporting to deepen its penetration into the local milieu, as well as conduct civic education, linked with the functioning local government and the life of the region.

The third pillar in the program format of regional television was to be film. It was calculated that films would occupy $10 \%$ of broadcast time in the mutual time slot. This would consists of reruns of popular Polish television series enhanced with films purchased in groups with the network in mind, which had been already broadcast on Polish national television. In addition, the number of films exchanged with the headquarters in Warsaw would be restricted, and an appropriate promotional strategy would be conducted with them.

Moreover, it was proposed to introduce a diverse form of programming as well as modern formats and genres allowing the whole program format to be more attractive and thereby attract more viewers. It was also accepted that the minimum amount of reruns would be $40 \%$ of the total broadcast material (Strategia Programowa, 2001, s. 19).

The second variant proposed for the development of regional television proposed in the 2001 strategy, was in the instance of their not being able to implement the whole set of programs offered by TVP S.A., they should become theme channels, specialized in certain subjects. It was assumed than, that the programs offered by regional television would concentrate on three distinct and separate sectors: news and local reporting, education, and culture. The news and information sector wold not differ from what was offered in the first variant. The educational sector would be the Open University Television, which would be dedicated to youth 
and adults interested in furthering their education. The OUT was to have two or three majors which people could choose from. The culture sector-ARTE Polska, was to be a group of programs focusing on culture, composed by linking the ARTE channel, with programs from the archives of TVP S.A. a well as the production of programs prepared especially for this time slot. The viewers were to be composed of anyone who would like to watch programs concerned with culture (Strategia Programowa, 2001, s. 19). The proposed changes were not however, implemented, because several months later, that is in October 2001, another document was issued which declared that TVP 3 Regional Television should be changed into a news-information channel. There were several causes for this decision by public broadcasting. Above all, it was pointed out that the trends on the television market, were for an increasingly defined program profile of television stations. The fact that a commercial news channel, TVN 24 was created, was also considered noteworthy. The officials at public broadcasting perceived in the planned changes, an opportunity to acquire a new, younger viewership (30-50 years old) which would be interested in a rapid and up-to-date news service. In addition, when referring to a media analysis done, the directors of Regional Television recognized that: "the reconstruction of the previous profile of regional television in linked with the introduction of a greater number of news broadcasts, on the regional as well as on the national level, as well as enhancing regional television with parliamentary, political reporting, social, cultural programs, as well as those focused on the economy - all the while maintaining and taking advantage of the previous assets of their own stations, and time slots, thereby assuring their position in the public television format" (Koncepcja, 2001).

One of the main assets of the proposed changes in the profile of local television, was to take advantage of the potential of local television, to provide a unique possibility on the Polish market, i.e. that of creating a current news service with an emphasis on local events. It was also pointed out that this would be on the one hand, as program format which would make it a rival of TVN 24 in the realm of news, however - on the other hand - would differentiate it from the competition because of its regional character. In addition it was pointed out that the linking of the potential of Local Television Stations of TVP S.A., the Television News Agency, as well as the Bureau of Regional Programs, would permit the construction of a Region - Country - World news service. 
This concept assumed the creation of a coherent news "ske leton" based on hourly national news and, at least, four local news broadcasts daily. These news programs were to be complemented by specialized subject news, and "general news" programs. The greatest emphasis was placed on assuring the viewers of a complimentary "view of the day" via a linking in one broadcast local and national news, which would "become unhooked" in 12 TVP affiliate stations, 6-8 times a day. On weekdays this would take up some 3 hours 15 minutes, and on Saturdays and Sundays, 4 hours and 30 minutes. The most important news slot would be primetime for news and commentary, that is from 19:30-22:00. It was planned that this format would have a unified character. It was to consist therefore of retransmission of the news from TVP 1, of Polish national journalistic and commentary programs, and end with local news.

As far as the concept of broadcasting went, it was planned to maintain the heretofore division of separate and joint time slots. The stations' own time slots would have an orderly and unified character, with a consistent - over the course of time - setting and scenography in the newsroomstudio and the studios of the affiliates, so that the viewers would obtain a precise, consistent image of TVP 3 Regional. Virtually all the program formats were to have this character (Koncepcja, 2001).

On the TVP 3 Regional channel there are from Monday to Friday, five time slots which are distinct and independently put forth by each of the twelve local stations of TVP S.A. (7.45-8:28, 15:45-16:28, 17:50-18:27, 18:45-19:28, 21:45-22:13) (Informacja, 2003).

As far as the program format, it was to have been a program linking the new function (while maintaining the aforementioned: local-national-world) and general. As the director at that time of TVP 3, Ryszard Pacławski said: "this will be a universal channel". In the format there are amongst others, entertainment programs, and every day at 22:00 a film is shown. Although these won't be class A films like in TVP 1 or TVP 2 they are supposed to be on a certain level (Rancewska, 2002). Such a concept gained adherents. It was pointed out that changing TVP 3 into a straight news channel, would mean the liquidation of its regional mission. There was an attempt to link both ideas. The new program format, as indicated, has an news backbone, but the framework is still that of Telewizja Regionalna (Żuliński, 2002).

In essence, thee were to have reports there from political, social, and economic events and information from the markets. In addition, viewers were to obtain information linked with the functioning of the law and be 
assured of their safety, and be informed of extraordinary events. Problems dealing with the countryside, ecology, culture, tourism and sports were to be dealt with, as well as the weather. As was mentioned in the document "the civic need for the viewers to participate in the running the country will be met by broadcasts from the parliament, transmissions and reports of the most important events taking place in our country, and a parliamentary report. The viewers of TVP will obtain solid information about that which their representatives, who hold public office are doing and if they are looking out for the interest of their electorate". Their calling card was to have been however, programs dedicated to national and ethnic minorities, religious groups, and cooperate with those region of Poland which are on its borders. The educational time slots were to have been preserved, as well as the Television Open University. Documentary and archival films were to have been an addition to the news profile of TVP 3 . Based on this element of universality, the proposed program format consisted of films, series, game shows, as well as entertainment programs (Koncepcja, 2001).

The TVP 3 channel was launched on March 3, 2002. It soon turned out however, in spite of the first positive evaluations within TVP, the project did not turn to be such a success as was initially foreseen. After six months of being on the air, the public television broadcaster publicly evaluated the situation by saying that the introduction of the new news-journalistic profile of TVP 3 should be treated as a success for channel "Regional 3" as well as for the local affiliates of TVP S.A. It was recognized that a new level of programs had been achieved, new viewers had been acquired, and ratings and market share had gone up (Koncepcja, 2001). Wiesław Godzic was of a different opinion however, and opined that the change in program from a regional television in TVP 3, to a news-reporting station, did not serve the concept of public television well. The resulted in a regression in the program quality in the local stations, and rendered them too strongly under the control of the headquarters in Warsaw. Maintaining the former strategy, dependent upon the portrayal of matters by a centrally controlled management and editing, would lead to the fall of the regional stations, and is an activity against the civic and cultural aspirations of the regions. In addition this author recognizes that the creation of Internet in public affairs from below and supplying local information, is an activity which the commercial stations will not undertake (Godzic, 2003, s. 59).

A noteworthy fact is that the change in program format in TVP 3 Regionalny as declared by TVP to be a news-information channel, was not 
evident from the very beginning. In earlier years, the strongest position, that is the most important program genre with reference to the amount of time occupied, broadcast in the common regional time slots, was that of feature films. In 2002, it was exactly this genre which occupied as much as $31.3 \%$ of the annual broadcast time of the common time slot. The viewership however, of those who were watching these news and information programs, which according to the broadcasters, was supposed to have been the raison d'etre of the new TVP Regionalna, was barely 2 percentage points higher than when they were showing feature films. Those programs broadcast in TVP 3 Regionalna in 2002 which wee based on facts (news, information, reporting, education, sports, religion, and documentary films) occupied $55.6 \%$ of the common program and dominated programs which were created (feature films, entertainment and music programs) whose level amounted to $35.2 \%$ but their proportion was not so high as to recognize them as deciding the programs character. In the next year of its operation, TVP Regionalna to a greater degree than in 2002, realized an information-news specialization imposed by the broadcaster. In the separate as well as in the common time slots, programs based on facts, (information, news, reporting, religion, self-help, sports and documentary films) dominated. In the separate time slots they occupied $77.3 \%$ of annual broadcast time, and in the common programs $64.2 \%$. Successive years brought a gradual growth in the share of news-information programs, in both the shared and separate time slots. This tendency indicates that the broadcaster systematically attempted to change the profile of the station into a news-information one. At the same time the proportion of common and shared time slots changed in some regions. For example in 2005 , as in earlier years, $82 \%$ of the air time of TVP 3 was occupied by common programs, and only $18 \%$ was from local television stations which broadcast on their separate time slots. In 2006 these proportions had hardly changed, as on the average $80 \%$ was of the common programs, and only $20 \%$ was independently created by the regional television stations (Informacja, 2002-2006).

At the same time, since the beginning of its activity, TVP 3 has had to contend with numerous difficulties. Above all, the main problem turned out to be the principles of the coexistence of the common and independent time slots of the local stations. In spite of the fact that every regional station which was part of TVP 3 possessed independent financing and administration, a far as the program format went, all affiliates were subject to the decisions of "Trójki" ("3"). The new information-reporting profile 
meant that all unexpected events from the public sphere were reported on regional TV. This in effect, significantly destabilized the program format the expense of the regional programs (Harazim, mat. TVP). In addition, from the moment when it commenced operations in 2002, the board of directors of public television regularly transferred a part of the means designated for local television stations to the disposition of the directors of the TVP 3 network. In this manner they thinned out those means which the local stations could have used to produce their own programs for their own regions. As a result the average broadcast time for their own programs for local television, was only $3 \frac{1}{2}$ hours in 2005 . The directors of TVP S.A. justified this process of merging regional programs was due to a lack of the adequate financial to make these programs (Raport, 2006, s. 27). In addition, it turned out TVP 3 's weakness was something that initially appeared to be an asset, that is the speed and alacrity with which it presented news and information. TVP 3 has been accused of, in relation to the competition, of being late in reporting the news, as well as of not fully covering the news. In addition TVP 3 has been noted for duplicating the content of other news programs, as well as of possessing a low of journalistic ability in general (Strzat, 2002, s. 22). Redesigning the program format for TVP 3 Regionalna was supposed to have been an idea for a better, more rational taking advantage of the technical and creative potential of the local television stations, however in practice in turned out differently. It's true that those programs produced in the regional television stations appeared almost $100 \%$ in the separate time slots, but in the common TVP 3 Regionalna slots their participation was decidedly less, and amounted to only $22.1 \%$ of the annual air time of that station. When a program from company headquarters is correlated, there is always the danger of a gradual elimination of regional subjects from the common TVP 3 Regionalna (Informacja, 2004).

The situation of TVP 3 Regionalna was also not improved by the fact that efforts were made to the maximum the viewership by making the program accessible on various platforms. TVP 3's signal could be received from land-based transmitters, or via satellite (W3 Satellite). This channel was also available on local cable networks. Discussions were held to put the channel on CYFRY+. TVP 3 has had its own Web page since September 2001, which is viewed monthly by some 8 thousand Internet users (Koncepcja, 2001).

It's also noteworthy that in October 2002, and therefore several months after TVP 3 Regiony started operations, public broadcasting in its 
development strategy for 2002-2006 indicated that: "further activities of the regional programs, created by the local affiliates of Telewizja Polska S.A. in their current form are too expensive and there are no means to pay for them. The creation and broadcast of regional programs now constitute approximately $20 \%$ of the operating costs of TVP S.A. whereas the viewers of these programs total only 3-5\%" (Strategia rozwoju, 2002, $\mathrm{s}$. A/1). This evaluation is concurrent with the proposition to modernize the bill concerning radio and television, which was supposed to have created a new entity: Polska Telewizja Regionalna S.A. bon January 1, 2003, which would create and broadcast national programs, which would appear on the regional time slots and create programs including news and reporting dealing with regional problems. Telewizja Polska Regionalna would be $100 \%$ owned by TVP S.A. (Strategia rozwoju, 2002, s. A/1). This solution however was not introduced into the bill, and the problem of regional television stations remained unsolved. The next proposed solution was to be the consolidation of all regional television stations. This idea was put forth in 2004, under the moniker of "A Strategy for the Transformation of Regional Television Stations". This strategy, which was proposed by Jan Dworak and Piotr Gaweł did not foresee such radical solutions as were lately employed in October 2007. In effect, the decision made, liquidated TVP 3 Regionalna, replacing it with TVP Info (Skoczek, 2009, s. 6).

TVP Info was created, as a news channel for Telewizja Polska, on October 6, 2007 on the basis of TVP 3. As previously, the station shared air time with the regional stations of TVP. TVP Info's program format is therefore composed of common time slots for the transmitting of the program throughout the technical range of the station, as well as to its local affiliates, where specific regional stations broadcast local news, reporting, and social programs. This channel, has maintained a regional-news profile. Since April 10, 2011, TVP Info's signal has also been transmitted on the Internet (Świerczyńska-Głownia, 2014, s. 99). The TVP Info channel ceased operating on August 31, 2013. This occurred as a result of a decision which was based, on the one hand, the possibility of creating a specialized TVP channel, that would have a news profile, and on the other hand, the possibility of returning back to the regional television on a grand scale. As the practice of creating hybrids has shown, a station aspiring to be a news channel, will have to compete on the market with TVN 24, while at the same time linking the tasks and roles of regional broadcaster, which as experience shows, just doesn't work out. The program format of these stations themselves was notoriously marginalized, and their fi- 
nancial situation effectively handicapped their day-to-day functioning, as well as deprived them of the dream of ever obtaining a competitive level on the media market.

After obtaining a concession issued by the KRRiT (National Radio and Television Council) (Koncesja, 2013) dated September 1, 2013, it started broadcasting, maintaining its prior name of TVP Info, as a specialized channel with a news-reporting profile. It continued to use its own band 16 OT TVP S.A. as well as those in common - programmed by a new entity: The Center for Regional Programs.

The role of regional programs consists of the time slots of Local Stations, and the common time slots directed by the Center for Regional Programs, which took on the "TVP Regionalna" channel, which also started broadcasting in its new structure on September 1, 2013 (Sprawozdanie, 2014, s. 22). The main goal of TVP Regionalna - that is of the 16 regional channels of TVP - was to have been a rapid and accurate informing of the public of all the most important events taking place in Poland and in its various regions. This time, a strong regional television network was to have been created, with powerful regional transmitters, from which every station would dispose of the proper cadre, technical base, frequency, as well as broadcast its own program. The profile was supposed to have been based on "regionality" as being the basic feature of the station, and be linked with local society via the presentation of a wide range of the local cultural heritage, harkening back to the idea of local patriotism ("heimat") and also guarantee the appropriate diversity of genres and territorial propositions regarding the programs transmitted (Zalewski, mat. TVP). This program profile meant that the station was to inform about local subjects, and promote the local society and patriotism. The program format was to have been based on the production via their own means, as well as co-produced programs, and transmitted on the rest of the local television stations. The programs of these local stations were to have been broadcast 18 hours a day, and on the common time slots for 13.5 hours (Świerczyńska-Głownia, 2014, s. 98). These regional programs were to have been accessible on land-based digital television, and on the mobile TVP Stream (TVP Regionalna, 2013).

The strategy accepted in 2013, regarding the regional stations, was kept in its basic form, until the end of 2015. Trying to determine the number of hours of programming a regional television station should produce, turned out to be unrealistic. In 2014, each of the 16 programs created by regional television stations, was transmitted for more than five 
hours a day, and on the common time slot for 19. On their own time slots, regional subjects composed from 41 to $76 \%$ of the air time. On the common time slots, this amounted to $62 \%$ of air time (Media, 2015, s. 21).

There was a breakthrough in the previous strategy at the turn of 2015 and 2016. The newly appointed director of TVP S.A., Janusz Daszczyński, presented a new concept regarding the functioning of the affiliates of regional TVP. The change consisted above all, of a modification of the regional philosophy and a retreat from "regional television" towards a "television of the regions - for people and closer to people". As the new director of TVP put it: „We are constructing our own universal model, which has a strong financial foundation, and is based on the most modern technology, and is an emanation of civic television. In a word - TVP 3 will soon be an inseparable part of Polish local regions" (Nowa, 2013).

Together with this change of philosophy, a perception of the role and place of regional TVP television stations has meant a new approach and assumes several essential changes. Above all, it is planned to change the heretofore program structure. The whole program format will be one time slot, created by each of the local stations and repeated several times a day (Pallus, 2015). It is planned to significantly limit or even do away with the common time slots for the benefits of local news. In the first stage, it is assumed that a morning breakfast show will be transmitted live, at breakfast time, with a light character, a sort of lifestyle-news program. This time slot would last from 7:00 to 8:15. In the first stage there are also plans for the afternoon time slot, which would last from 17:30. In effect, in each of the regions, there would be 5 hours 15 minutes of programs produced by them, daily (Nowa, 2013). Over time it was determined that 16 hours of regional programming would be broadcast for specific viewers in specific regions. The 16 hours of transmissions a day would be composed of two 6-hour blocks of programs (broadcast from 7:00 to 13:00, and from 13:00 to 19:00) and one 4-hour block (19:00-23:00) (Pallus, 2016). The idea was that the 6-hour block could be rerun in fragments in the remaining time slots, and thus be watched by various groups of viewers, who are interested in a given subject. In addition, the $6+6+4$ scheme, is also to be used in for programs of a universal, non-regional character, which will be accessible to all viewers in the 16 regions. However the main core of the program will be created in an original manner by all of the regions, while maintaining certain elements in common. These programs will offer the freshest news from the region, with live reports, reviews of the regional print media and Internet sites, a summary of the previous day, conversa- 
tions with guests, and descriptions of what the best television programs on a given day. In addition there would be self-help and entertainment programs (Nowa, 2013).

The next element would be a change in the manner of disseminating program content as well as creating a platform for distributing the programs offered in such a manner, as to take maximum advantage of means of reaching the public, getting not only to television viewers, but also to Internet users. Therefore it is planned to expand the target group, as well as meet the demands of the digital market. It is also planned that in every one of the 16 regions, there would be a web page, which would issue modern Internet services, directed to the inhabitants of the regions sending them video material via television, and information prepared only for Internet users. Content made available on the Internet, would be appropriate to Internet channels of consumption. In order to make this more attractive for Internet users, it is planned to enrich the content using Internet transmission, employ local journalists, or also through the use of popular applications, enable the transmission of events live, via mobile devices. In addition it is also planned to use social TV, that is using either a television screen, computer monitor, or Smartphone or tablet, as a forum to present the opinions of viewers, whose various types of content, and even live discussions conducted on various types of social media. Internet news sites could also be the first choice for local news (Nowa, 2013).

The manner in which content is obtained was also supposed to have been subject to change. It was planned to emphasize civic journalism. A social platform was created, which would be integrated with the media and thereby enable the collection and publication of video and photo content, from Internet users from Poland and the world, in one place. Selected content would be presented in television programs or could become the inspiration materials realized for the needs of local WWW services as well as television and radio programs (Nowa, 2013).

The heretofore logo of regional television has been replaced by the TVP 3 logo.

The proposed changes have been delayed due to the successive change in the board of directors of TVP S.A. The future of the regional television stations remains an open question. There is no doubt however, that leaving it in the organizational and financial state it had been in until recently, would have signaled its rapid demise. Activities linked with the restructuring of its functioning, and what goes along with this, changes in how the regions are financed, would seem to be not just a need but 
a necessity, so that TVP would remain present on the market at the local level. The enormous potential not taken advantage of by commercial television, may be lost forever. It's worth remembering, that in 1999, when the great reform of TVP was initiated, there has not been found a formula to take advantage of regional television, as a fortune was there, consisting of $38 \%$ of TVP as a whole, almost $40 \%$ of TVP's workforce was there, and almost $50 \%$ of investment were designated for local television. As a total, the cost of the functioning of the 12 regional television stations, were - and what's important still are! - almost equal to that delegated to the functioning of TVP 1 (Reforma, 1999, s. 118).

\section{Bibliography}

Godzic W. (2003), wypowiedź podczas konferencji: Rynek audiowizualny w Polsce - ocena i perspektywy zorganizowanej w Warszawie w dniach 28-31 października 2003 roku, w: Rynek Audiowizualny w Polsce. Ocena i perspektywy, red. J. Adamowski, Oficyna Wydawnicza ASPRA-JR, Warszawa.

Grzybczak J. (2002), Telewizja regionalna w reformie TVP, „Zeszyty Prasowe”, R. XLV, nr 1-2 (169-170), Kraków.

Harazim K. (2013), TVP S.A. - Regionalna Trójka, Materiały TVP, Katowice.

Jakubowicz K. (1996), Publiczna i prywatna telewizja w Polsce, w: Media i dziennikarstwo w Polsce 1989-1995, red. G. G. Kopper, I. Rutkiewicz, K. Schliep, Ośrodek Badań Prasoznawczych Uniwersytetu Jagiellońskiego, Kraków.

Mielczarek T. (1996), Telewizja Polska S.A. w latach 1994-1996, „Zeszyty Prasoznawcze", R. XXXIX, nr 3-4 (147-148), Kraków.

Miszczak E. (2014), wywiad udzielony autorce w: W. Świerczyńska-Głownia, Ewolucja rynku telewizyjnego w Polsce. Analiza przypadku TVP i TVN, Wydawnictwo Uniwersytetu Jagiellońskiego, Kraków.

Nierenberg B. (2007), Publiczne przedsiębiorstwo medialne. Determinanty, systemy, modele, Wydawnictwo Uniwersytetu Jagiellońskiego, Kraków.

Nowa odstona telewizji regionalnej - na ekrany wraca tvp3! (2013), Centrum Informacji TVP, Telewizja Polska S.A., Warszawa, http://wroclaw.tvp.p1/23208552/ nowa-odslona-telewizji-regionalnej-na-ekrany-wraca-tvp3, 09.12.2015.

Pallus P. (2015), Będq duże zmiany w TVP Regionalnej. „Powstanq anteny 16 regionów”, http://www.wirtualnemedia.pl/artykul/beda-duze-zmiany-w-tvpregionalnej-powstana-anteny-16-regionow, 20.12.2015.

Pallus P. (2016), TVP3 zastapita TVP Regionalnq. Nowa oprawa graficzna i poranne pasma, http://www.wirtualnemedia.pl/artykul/tvp3-zastapila-tvp-regionalnanowa-oprawa-graficzna-i-poranne-pasma-wideo, 5.01.2016.

Rancewska A. (2002), Regionalna Trójka, „Przegląd”, nr 8, http://www.tygodnikprzeglad.pl/regionalna-trojka/, 20.12.2015. 
Różycka M. (2013), Globalizm a lokalizm w perspektywie medialnej, „Naukowy Przegląd Dziennikarski”, nr 4, Kraków.

Skoczek T. (2009), Media publiczne w Polsce, Mazowiecka Oficyna Wydawnicza, Warszawa.

Stempień J. (2002), Bóle reformatora, Media - Polska, czerwiec 1998, w: J. Grzybczak, Telewizja regionalna $w$ reformie TVP, „Zeszyty Prasowe”, R. XLV, nr 1-2 (169-170), Kraków.

Strzat $w$ dziesiatke (2002), Press, Materiały udostępnione przez TVP.

Świerczyńska-Głownia W. (2014), Ewolucja rynku telewizyjnego w Polsce. Analiza przypadku TVP i TVN, Wydawnictwo Uniwersytetu Jagiellońskiego, Kraków.

TVP Regionalna - nowa, lokalna telewizja startuje 1 września (2013), Telewizja Polska S.A., Warszawa, www.tvp.pl, 09.12.2015.

Zalewski M., Prezentacja, Materiały udostępnione przez TVP.

Żuliński L. (2002), Trójka na piątkę, „Trybuna”, 15.03.2002.

\section{Documents:}

Główne założenia reformy Radiofonii i Telewizji (1990), Komisja do Spraw Reformy Radia i Telewizji, Warszawa.

Informacja o Podstawowych Problemach Radiofonii i Telewizji (2002), Krajowa Rada Radiofonii i Telewizji, Warszawa, http://www.krrit.gov.pl/Data/Files/_public/ Portals/0/sprawozdania/spr2002/inf2002.pdf, 09.12.2015.

Informacja o Podstawowych Problemach Radiofonii i Telewizji (2003), Krajowa Rada Radiofonii i Telewizji, Warszawa, http://www.krrit.gov.pl/Data/Files/_public/ Portals/0/sprawozdania/spr2003/inf2003.pdf, 09.12.2015.

Informacja o Podstawowych Problemach Radiofonii i Telewizji (2004), Krajowa Rada Radiofonii i Telewizji, Warszawa, http://www.krrit.gov.pl/Data/Files/_public/ Portals/0/sprawozdania/spr2004/inf2004.pdf, 09.12.2015.

Informacja o Podstawowych Problemach Radiofonii i Telewizji (2005), Krajowa Rada Radiofonii i Telewizji, Warszawa, http://www.krrit.gov.pl/Data/Files/_public/ Portals/0/sprawozdania/spr2005/inf2005.pdf, 09.12.2015.

Informacja o Podstawowych Problemach Radiofonii i Telewizji (2006), Krajowa Rada Radiofonii i Telewizji, Warszawa, http://www.krrit.gov.pl/Data/Files/_public/ Portals/0/sprawozdania/spr2006/inf2006.pdf, 09.12.2015.

Koncepcja TVP3 Regionalna. Profil informacyjno-publicystyczny (2001), Telewizja Polska S.A., Biuro Programów Regionalnych, Warszawa.

Koncesja Nr 522/2013-T.

Media publiczne. Raport z działalności w 2014 roku (2015), Krajowa Rada Radiofonii i Telewizji, Departament Mediów Publicznych, Warszawa.

Przyszłość telewizji publicznej w Polsce. Tezy do dyskusji (1995), Krajowa Rada Radiofonii i Telewizji, Warszawa.

Raport otwarcia: rynek radiowo-telewizyjny w Polsce (2006), Krajowa Rada Radiofonii i Telewizji, Warszawa. 
Reforma Telewizji Polskiej S.A. Rozwiazania Systemowe (1999), dokument przyjęty przez Zarząd Spółki Telewizja Polska S.A. na posiedzeniu nr 31/99 w dniu 6 maja 1999 r., Warszawa.

Rozwiazanie prawne i organizacyjne $w$ zakresie struktury organizacyjnej telewizji polskiej S.A. oraz rozwiqzania zastosowane $w$ wybranych europejskich telewizjach publicznych (2003), Telewizja Polska S.A., Biuro Zarządu Zespołu ds. Strategii i Organizacji, Warszawa.

Sprawozdanie Zarzadu z wykorzystania przez Telewizję Polska S.A. wpływów z opłat abonamentowych na realizację misji publicznej w 2013 roku (2014), Telewizja Polska S.A., Załącznik do Uchwały Nr 122/2014 Zarządu Spółki TVP S.A. z dnia 7 marca.

Strategia Programowa Telewizji Polskiej do 2004 roku (2001), Telewizja Polska S.A., Warszawa.

Strategia Programowa TVP S.A. (2000), Biuro Polityki i Koordynacji Programowej, Telewizja Polska S.A., Warszawa.

Strategia Rozwoju Spółki Telewizja Polska S.A. 2002-2006 (2002), Telewizja Polska S.A., Warszawa.

Ustawa z dnia 29 grudnia 1992 roku o radiofonii $i$ telewizji, Dz. U. 1993, Nr 7 , poz. 34 .

\section{Polska Telewizja Regionalna - na granicy pomiędzy telewizją regionalną a krajową. Ewolucja charakteru regionalnych stacji telewizyjnych}

\section{Streszczenie}

Od upadku monopolu Telewizji Polskiej, kwestia Oddziałów Terenowych TVP pozostała nierozwiązana, de facto, do dnia dzisiejszego. Na przestrzeni lat podejmowane były liczne próby określenia statusu oraz zasad funkcjonowania oddziałów w strukturze TVP, jak również poszukiwano koncepcji na określenie ich miejsca oraz roli na rynku telewizyjnym. Podejmowane przez lata próby zrestrukturyzowania regionów nie przyniosły oczekiwanych rezultatów. Proponowane rozwiązania, począwszy od koncepcji „sieci” w latach 90-tych, poprzez próbę integracji programowej i zarządczej pod koniec XX wieku, a na próbach sprofilowania anten skończywszy, zamiast poprawy sytuacji pogrążały oddziały w jeszcze większym chaosie i pogarszały ich, i tak trudną, sytuację finansową. Zmianę tej sytuacji miała przynieść nowa, zaproponowana pod koniec 2015 roku, koncepcja funkcjonowania Oddziałów Terenowych TVP S.A., zakładająca reorientację filozofii regionów i odejście od „telewizji regionalnej” na rzecz „telewizji regionów”. Zmiany na poziomie Zarządu TVP zatrzymały planowaną reformę. Artykuł ukazuje chronologię planowanych i przeprowadzonych reform od 1990 do 2015 roku, w aspekcie profilu anten oraz oferty programowej Oddziałów Terenowych TVP S.A.

Słowa kluczowe: telewizja regionalna, strategia programowa, reforma, TVP S.A., ramówka. 